Giedrewicz-Niewińska A., Involvement of employees in corporate governance in a European company, „Ekonomia i Prawo. Economics and Law”, Polszakiewicz B., Boehlke J. (ed.), Vol. 14, No. 3/2015, pp. 327-340. DOI: http://dx.doi.org/10.12775/EiP.2015.021.

\title{
INVOLVEMENT OF EMPLOYEES IN CORPORATE GOVERNANCE IN A EUROPEAN COMPANY
}

\author{
SUMMARY
}

The aim of this paper is to consider the meaning of employee involvement in practical functioning of European companies. The basis for this evaluation will be not only legal provisions but also practical operation of European companies in the market. This will allow us to learn about the level and scope of employee involvement in corporate governance at the transnational level, and to determine whether this is in fact the future direction of development of this type of governance. The considerations will be carried out utilizing literature review and comparative law analysis as methodologies. The analysis of the legal framework will be complemented by an empirical approach that is necessary to identify the European companies operating in the market.

Keywords: corporate governance; industrial relations; involvement of employees; European company

JEL Classification: K310

Aneta Giedrewicz-Niewińska, University of Bialystok, Faculty of Law, Department of Labour Law, ul. Mickiewica 1, 15-213 Bialystok, Poland, phone: +48 8574571 56, e-mail: a.niewinska@uwb.edu.pl. 


\section{INTRODUCTION}

Generally speaking, corporate governance relates to the way in which companies are managed and regulated ${ }^{1}$. One of the main causes of the financial crisis whose effects are still being felt by the population is poor management of enterprises, focused exclusively on profit maximization. Negative experiences often cause that in today's world there is a growing interest in a model of enterprise where employees are guaranteed involvement in corporate governance.

Currently, the European model of enterprise has received a new universal legal framework providing for involvement of employees in transnational companies whose activities go beyond local markets. Among these companies, a European company has a special importance due to its constant growth and developed forms of employee involvement.

When creating the legal framework that would govern this type of business activity, its authors assumed it would enable employees to be involved in corporate governance in a way that would take account of the tradition of management present in the entities forming a European company. The legal framework for this bold assumption has been created by Regulation 2157/2001/EC of 8 October 2001 on the Statute for a European Company $(\mathrm{SE})^{2}$, Directive 2001/86/EC of 8 October 2001 supplementing the Statute for a European company with regard to the involvement of employees ${ }^{3}$, and, in Poland, the Act of 4 March 2005 on European Economic Interest Grouping and European Company ${ }^{4}$. The role of the right of employees to be involved in matters and decisions affecting a European company is emphasized by Regulation 2157/2001, stating that the provisions of the Directive form an indissociable complement to the Regulation and must be applied concomitantly.

The aim of this paper is to consider the meaning of employee involvement in practical functioning of European companies. The basis for this evaluation will be not only legal but also practical operation of European com-

1 A. Szymańska, P. Włodarczyk, Przedstawicielstwo pracowników w radzie spótki w krajach cztonkowskich UE, „Studia Prawno-Ekonomiczne”, Vol. 86/2012, p. 334.

2 Council Regulation (EC) No. 2157/2001 of 8 October 2001 on the Statute for a European company (SE), OJ L 294/2001.

${ }_{3}$ Council Directive 2001/86/EC of 8 October 2001 supplementing the Statute for a European company with regard to the involvement of employees, OJ L 294/2001.

${ }^{4}$ Ustawa z dnia 4 marca 2005 r. o europejskim zgrupowaniu interesów gospodarczych i spótce europejskiej (Act of 4 March 2005 on European Economic Interest Grouping and European Company), Dz.U. No. 62, item 551. 
panies in the market. This will allow us to learn about the level and scope of employee involvement in corporate governance at the transnational level, and to determine whether this is in fact the future direction of development of this type of governance.

\section{THE METHODOLOGY OF RESEARCH}

Answering the questions and the realization of the objectives of this paper will require the use of the comparative law method as well as a review of literature relevant to the research problem. Analysis of the legal framework will be supplemented by an empirical approach necessary to identify the European companies operating in the market. This approach allows one to compare the results of two research studies. Documents and statistical data from the ETUI (European Trade Union Institute) will be examined. In addition, this study will also take into account the research on agreements concerning employee involvement mechanisms contained in the previously registered European companies.

\section{THE RESEARCH PROCESS}

The first part of the article presents theories of corporate governance that are of importance to the topic considered. The second part examines legal framework conducive to involvement of employees in corporate governance in a European company. The third part of the article presents an analysis of the statistical data relating to European companies. The fourth part shows the results of research on the content of the so-far-concluded agreements on involvement of employees in the management of a European company. Conclusions have been contained in the last part of the article.

\section{1. "CORPORATE GOVERNANCE" EXPLAINED}

At the beginning of the considerations, it must be noted that in Polish national law there is no legal definition of the term "corporate governance". In the realm of theoretical analysis, various ways of explaining this term have been presented, depending on the field of science dealing with this issue. A detailed presentation of these ways is beyond the scope of the present paper.

An analysis of these concepts makes it possible to assume that the core of corporate governance is the creation of a system consisting of interde- 
pendent and complementary legal and economic institutions, aiming to ensure proper and economically efficient operation of joint stock companies and to mitigate or resolve conflicts of interest of those involved in the company ${ }^{5}$.

\subsection{LEGAL SOLUTIONS CONCERNING EMPLOYEE INVOLVEMENT IN CORPORATE GOVERNANCE IN A EUROPEAN COMPANY}

Because of the subject of this paper, the considerations to follow shall focus on determining which particular legal solutions should promote employee involvement in corporate governance in a European company and what its acceptable design should be. As a preliminary point, it should be noted that in this regard EU provisions use the term "involvement of employees", understood as a mechanism comprising information, consultation and participation through which employees' representatives may have an impact on decisions taken within the company (Article 2 (h) of Directive 2001/86). These both terms (involvement and employee involvement) shall hereinafter be used interchangeably.

One of the most important solutions, which - as it seems - should in practice ensure the presence of employees in corporate governance, is that the registration of a European company is dependent upon prior determination of the issues of employee involvement mechanisms (Article 12 of Regulation 2157/2001).

Another specific solution is to enable the employee representatives and the management to autonomously develop employee involvement in the management of their SE. In fact, there is a rule of priority of negotiated solutions regarding employee involvement mechanisms in corporate governance.

A legal institution guaranteeing involvement of employee stakeholders in corporate governance is the so-called "statutory model" of involvement ("standard rules"). Generally speaking, it is applicable in the following two situations: a) where the parties so agree, or b) where by the stipulated deadline no agreement on employee involvement has been concluded (Article 7 of Directive 2001/86). The statutory model is based on the "before and after" principle, according to which employee rights in force before the establishment of a European company should provide the basis for employee rights of involvement in the SE.

${ }^{5}$ K. Oplustil, Instrumenty nadzoru korporacyjnego (corporate governance) w spótce akcyjnej, Wydawnictwo C.H. Beck, Warszawa 2010, pp. 3-8. 
Forms of employee involvement in corporate governance are based on the German system ${ }^{6}$. In accordance with a similar model adopted in an SE, employees have the right to be informed and consulted, generally through a representative body, and the right to participation meaning the ability to elect or appoint some of the members of the supervisory or administrative organ of the company or to oppose the appointment (Article $2(\mathrm{k})$ of the Directive 2001/86).

There is no doubt that out of these two forms, it is the participation that ensures the fullest employee involvement in corporate governance. It is at the heart of a European debate on corporate governance, causing controversy with regard to the balance of powers between shareholders and other stakeholders, and the correlation between the structure of the company and its productivity ${ }^{7}$. However, a question arises whether that form existing in a European company will develop, since in the course of the negotiations, employees may even refrain from being involved in the bodies of the company or reduce the level of this involvement. This does not apply only to an SE established by transformation.

\subsection{A EUROPEAN COMPANY AND EMPLOYEE INVOLVEMENT IN CORPORATE GOVERNANCE IN LIGHT OF STATISTICAL DATA}

The legal solutions presented so far make it possible to join the economic potentials of companies from different Member States and to involve employees in the corporate governance in a European company. This should therefore be reflected in the statistics. It seems that a condition of registration of a European company, in the form of determination of employee involvement mechanisms, should result in the broad scope of application of employee involvement in corporate governance. Therefore, the way of functioning of European companies in the member countries belonging to the EEA has been subjected to closer scrutiny. For this purpose, the data collected by the ETUI till March 2014 have been analysed ${ }^{8}$.

${ }^{6}$ J. Wratny, Partycypacja pracownicza. Studium zagadnienia w warunkach transformacji gospodarczej, Wydawnictwo Instytutu Pracy i Spraw Socjalnych, Warszawa 2002, pp. 28-29.

${ }^{7}$ W. Njoya, Employee Ownership in the European Company: Reflexive Law, Reincorporation and Escaping Co-determination, "Journal of Corporate Law Studies", Vol. 11, No. 2/2011, p. 274.

${ }^{8}$ ETUI, Facts $\mathcal{E}^{2}$ Figures, http://www.worker-participation.eu (15.03.2015). 
Table 1. Geographical distribution of SEs

\begin{tabular}{|c|c|c|}
\hline $\begin{array}{l}\text { NUMBER OF SES REGISTERED } \\
\text { IN INDIVIDUAL COUNTRIES }\end{array}$ & $\begin{array}{c}\text { NUMBER OF SES EMPLOYING OVER } 5 \text { WORKERS, } \\
\text { THE SO-CALLED "NORMAL SES" }\end{array}$ & $\begin{array}{l}\text { "EMPTY SES", "SHELF } \\
\text { SES", "UFO SES" }\end{array}$ \\
\hline 1. Czech Republic - 1495 & $66(4.4 \%)$ & $1429(95.6 \%)$ \\
\hline 2. Germany - 292 & $138(47.3 \%)$ & $154(52.7 \%)$ \\
\hline 3. Slovakia -92 & $4(4.3 \%)$ & $88(95.7 \%)$ \\
\hline 4. United Kingdom -61 & $5(8.2 \%)$ & $56(91.8 \%)$ \\
\hline 5. Holland -33 & $13(39.4 \%)$ & $20(60.6 \%)$ \\
\hline 6. Luxemburg -27 & $9(33.3 \%)$ & $18(66.7 \%)$ \\
\hline 7. France -23 & $13(56.5 \%)$ & $10(43.5 \%)$ \\
\hline 8. Austria - 19 & $10(52.6 \%)$ & $9(47.4 \%)$ \\
\hline 9. Cyprus - 14 & $6(42.8 \%)$ & $8(57.2 \%)$ \\
\hline 10. Belgium -10 & $4(40.0 \%)$ & $6(60.0 \%)$ \\
\hline 11. Ireland -10 & $2(20.0 \%)$ & $8(80.0 \%)$ \\
\hline 12. Estonia - 6 & $5(83.3 \%)$ & $1(16.7 \%)$ \\
\hline 13. Liechtenstein -6 & $1(16.7 \%)$ & $5(83.3 \%)$ \\
\hline 14. Hungary -5 & $4(80.0 \%)$ & $1(20.0 \%)$ \\
\hline 15. Sweden -5 & $1(20.0 \%)$ & $4(80.0 \%)$ \\
\hline 16. Malta -5 & $0(0.0 \%)$ & $5(100.0 \%)$ \\
\hline 17. Latvia -4 & $3(75.0 \%)$ & $1(25.0 \%)$ \\
\hline 18. Norway -4 & $2(50.0 \%)$ & $2(50.0 \%)$ \\
\hline 19. Denmark - 3 & $0(0.0 \%)$ & $3(100.0 \%)$ \\
\hline 20. Spain -3 & $0(0.0 \%)$ & $3(100.0 \%)$ \\
\hline 21. Italy -2 & $1(50.0 \%)$ & $1(50.0 \%)$ \\
\hline 22. Lithuania -2 & $1(50.0 \%)$ & $1(50.0 \%)$ \\
\hline 23. Poland -2 & $0(0.0 \%)$ & $2(100.0 \%)$ \\
\hline 24. Finland -1 & $1(100.0 \%)$ & $0(0.0 \%)$ \\
\hline 25. Portugal -1 & $0(0 \%)$ & $1(100.0 \%)$ \\
\hline Total -2125 & 289 (13.6\%) & 1836 (86.4\%) \\
\hline
\end{tabular}

Source: Own study based on: ETUI, Facts \& Figures, http://www.worker-participation.eu (15.03.2015).

The analysis of the data included in table 1 lead to the conclusion that the country with largest number of registered SEs as yet is the Czech Republic with 1495 SEs (70.4\%) followed by Germany with the total 
of 292 SEs (13.7\%). In addition, countries that can boast about a significant number of established SEs include Slovakia with 92 SEs (4.3\%) and the United Kingdom with 61 SEs (2.9\%). In total, these four countries have 1940 SEs (91.3\%). In Poland, there are two registered SEs. The unusual dynamics in terms of SE registrations in the Czech Republic is something quite amazing. In recent years, almost $80 \%$ of SEs are established in that particular country9.

On the other hand, in 6 out of the 31 EEA countries no European companies have been registered (Bulgaria, Croatia, Greece, Romania, Slovenia, Iceland $^{10}$ ).

The data contained in table 1 have generally been divided into two groups and characterized from the perspective of industrial relations ${ }^{11}$. The first group includes European companies referred to in the literature as "normal SEs" conducting economic activity and having over 5 employees. The second group includes "empty SEs", which are economically active but have no employees; "shelf SEs" - which are inactive ("sleeping beauties"12); and "UFO SEs", for which only few details, such as their names, are known from the registers.

It must be noted that only 289 SEs employ more than 5 staff members and conduct economic activity. This result is surprising, especially when considering the fact that Regulation 2157/2001 makes the company's registration dependent on determination of employee involvement mechanisms. The analysis conducted shows that the vast majority of established SEs do not employ as many as 5 workers. As is clear from the case law of the German courts, in such a case it is not required to have the issue of employee involvement determined prior to the SE's registration ${ }^{13}$. It has been stated that the condition of registration of a European company aimed at employee involvement in corporate governance, rests on the assumption that both the companies involved $^{14}$ and the European company actually have some employees. This leads

\footnotetext{
${ }^{9}$ Ibidem.

10 Ibidem.
}

11 B. Keller, F. Werner, The establishment of the European Company: The First Cases form an Industrial Relations Perspective, "European Journal of Industrial Relations", Vol. 14, No. 2/2008, p. 154.

${ }_{12}$ R. van het Kaar, The European Company (SE) Statute: up against increasing competition?, “Transfer: European Review of Labour and Research”, Vol. 17, No. 2/2011, p. 196.

${ }_{13}$ The registration court supported the use of this type of interpretation in relation to Article 12 paragraph 2 of the Regulation 2157/2001: OLG Düsseldorf, Beschl. v. 30.03.2009 - I-3 Wx 248/08, "Zeitschrift für Wirtschaftsrecht”, Vol. 19/2009, p. 918.

14 "Participating companies" means the companies directly participating in the establishing of an SE. 
to the conclusion that "empty SEs" and "shelf SEs" may be used in order to avoid employee involvement in corporate governance.

The largest number of "normal SEs" have been registered within the territory of Germany (138). In turn, out of the 1495 European companies established in the Czech Republic, only 66 ones may be described as above. Subsequently, this type of SEs can be found in France (13), the Netherlands (13) and Austria (10). It is worth noting the presence of "normal SEs" in the United Kingdom (5), which at the initial period of the EU regulation (that is up to 2004) did not record even one company of this kind ${ }^{15}$. This proves the emergence of employee involvement in a country where so far the major role in the collective employment relations has been played by trade unions and collective bargaining agreements concluded through negotiations ${ }^{16}$.

In five countries, despite established SEs, there are no "normal SEs" Malta, Denmark, Spain, Poland, Portugal.

The research has shown ${ }^{17}$ that the established European companies are dominated by the two-tier model of corporate governance, with the administrative body and the supervisory body (81\%). In the Czech Republic the twotier system of governance is present in $98 \%$ of the country's registered SEs. This is a rather obvious result considering the fact that in most cases the directors of a company choose the management system in force at the country of registration.

There are, however, exceptions to this rule. It is interesting that in turn the larger part of SEs registered in Austria are companies utilizing the onetier model (79\%). The one-tier system is also chosen by SEs registered in Germany $(38.4 \%$ ). It seems that the decision to use this management model may result from the company shareholders' need to "escape" from the control of the supervisory body ${ }^{18}$. Nevertheless, it is difficult to agree with a view expressed in the literature, according to which this is also about "escaping" from the influence of employees being members of the supervisory body, since the involvement of the latter is ensured in the one-tier system of corporate governance.

15 B. Keller, F. Werner, op. cit., p. 158.

${ }^{16}$ R. Taylor, Industrial democracy and the European traditions, "Transfer: European Review of Labour and Research", Vol. 11, No. 2/2005, p. 157.

17 ETUI, op. cit.

${ }^{18}$ B. Keller, F. Werner, op. cit., p. 167. 
Table 2. Involvement of employees

\begin{tabular}{|c|c|}
\hline \multicolumn{2}{|c|}{ TOTAL NUMBER OF SES - 2125 INCLUSIVE OF THE NUMBER OF SES WITHOUT INVOLVEMENT OF EMPLOYEES - 2020} \\
\hline $\begin{array}{c}\text { Number of SES with information, consultation and participation - } \\
54 \text { (Germany, Austria, France, Cyprus, Hungary) }\end{array}$ & $\begin{array}{c}\text { Number of SEs with information } \\
\text { and consultation }-51\end{array}$ \\
\hline $\begin{aligned} \text { Number of employee representatives in a SEs bodies - 156 } \\
\text { Nationality of employee representatives: Germany }-120, \\
\text { other countries - 36 (including the Netherlands }-7, \\
\text { Austria, France, Poland, United Kingdom }-4 \text { each) }\end{aligned}$ & \\
\hline
\end{tabular}

Source: Own study based on: ETUI, Facts \& Figures, http://www.worker-participation.eu (15.03.2015).

The analysis of employee involvement in corporate governance must be limited to the mere 289 SEs registered as "normal". Among these SEs, only in 105 (36.3\%) agreements on the involvement have been concluded. Nearly half of them (51) have negotiated a procedure for information and consultation in the form of a representative body. However, they do not provide for employee involvement in a body of the company. In turn, in the remaining 54 SEs there is information, consultation and participation alongside each other. In these SEs, which have predominantly been registered within the territory of Germany, their employees enjoy the strongest form of corporate governance.

In total, employees' representatives from 16 countries are members of SE's bodies. These figures prove the internationalization of the employee party because among the members of the European company's bodies are not only representatives of the employees employed in the country of its registered office, but employees from other countries are also represented. A good example of this are, included in this group, 4 representatives from Poland, which - as should be noted - does not have a registered SE with employees. This leads to the conclusion that Polish entrepreneurs and employees learn about a model of involvement in corporate governance in a European company not only when their registered offices are located in Poland, but also when they participate in the establishment of this entity in other member states of the European Union. 


\subsection{EMPLOYEE INVOLVEMENT IN CORPORATE GOVERNANCE IN LIGHT OF CONCLUDED AGREEMENTS}

Below are the results of research conducted by Eidenmüller, Hornuf and Reps ${ }^{19}$ concerning the content of agreements on employee involvement mechanisms in a European company. The authors have tried to determine whether the parties to agreements on employee involvement use the possibility to negotiate more effective rules of employee involvement in corporate governance than those resulting from statutory rules (the so-called "standard rules").

The research was conducted between June and September 2010 based on 15 agreements concluded in European companies, as a rule registered in Germany, and in one case - in Austria. Furthermore, the above analysis was supplemented and its conclusions were reinforced by observations from earlier research carried out on 45 European companies registered in Germany ${ }^{20}$. The choice of agreements binding mainly in SEs head-quartered in Germany is dictated by the largest number of the so-called "normal SEs" created in this country. In addition, in some countries there is no obligation to ensure the involvement of employees, and this is seemingly why negotiations on such an agreement have not been conducted there at all (eg. in the United Kingdom) ${ }^{21}$.

The content of the agreements examined shows that the most significant changes were those related to the procedure for informing and consulting employees. Most of all, an expansion of a list of issues that would be the subject of information and consultation procedures in relation to provisions contained in Directive 2001/86 was observed. It is interesting that the parties to these agreements have decided to include in this procedure certain additional issues omitted in the Directive, such as human resources, labour law, $\mathrm{OSH}$ and severance pay.

Changes were also spotted in comparison to the German national provisions transposing Directive 2001/86 22 . These related to the matter of composition of a representative body for the employees of an already-established

${ }^{19}$ H. Eidenmüller et al, Contracting Employee Involvement: An Analysis of Bargaining Over Employee Involvement Rules for a Societas Europaea, "Journal of Corporate Law Studies", Vol. 12, No. 2/2012, p. 201.

${ }^{20}$ R. Köstler, E. Rose, Mitbestimmung in der Europäischen Aktiengesellschaft (SE) Betriebs- und Dienstvereinbarungen, Verlag. Bund-Verlag, Frankfurt am Main 2011.

${ }^{21}$ H. Eidenmüller et al., op. cit., p. 216.

${ }^{22}$ Gesetz vom 22.12.2004 über die Beteiligung der Arbeitnehmer in der Europäischen Gesellschaft (SE-Beteiligungsgesetz) (The Act of 22.12.2004 on employees involvement in the European company), BGBI. I S. 3675, 3686; Gesetz zur Ausfübrung der Verordnung (EG) Nr. 2157/2001 des Rates vom 8.10.2001 über das Statut der Europäischen Gesellschaft (SE) (SE-Ausfübrungsgesetz - 
European company. It should be emphasized that in the majority of agreements (80\%), trade union members were admitted to meetings of the representative body.

As to employee involvement in the bodies of a European company (participation), the research conducted has revealed that there are only a few innovative negotiated solutions. Here, parties to the agreements benefit from the solutions provided by the legislature to a greater extent than in the case of the solutions regarding employees' right to be informed and consulted. This generally means that the level of employee representation present in companies involved in the establishment of a European company is transferred to the latter. It should be emphasized that most changes were related to the structure and size of the body of a European company. It is all the more interesting because, in accordance with the position adopted in the literature ${ }^{23}$, these issues need not be the subject of negotiations between the employees' representatives and the bodies of the companies involved.

According to the authors of the research, the lack of limitations on employees' right to participation in the concluded agreements is dictated by shareholders' fear of the company's negative reception by the general public; deterioration of corporate reputation ${ }^{24}$. "Ideological reasons" that arise when representatives of trade unions are involved in the negotiations were considered the probable causes of absence of "creative" solutions in the case of participation. They negotiate terms of agreement not only on behalf of the employees, but actually also on behalf of the trade unions. "Loss aversion" is closely linked to this. Assuming that labour law is the result of many years' struggle for employees and trade union rights, any resignation would be perceived as a loss for both the employees and the trade unions. Hence the increasing positive attitude to standard rules.

\section{CONCLUSIONS}

The presented research shows that employees are present in the corporate governance of European companies. To shape the functioning of the corporate governance, a method of negotiations is used, but not in relation to any

SEAG) (Act implementing the Council Regulation (EC) No. 2157/2001 of 8 October 2001 on the Statute for a European company (SE)), BGBI. I S., 3675.

${ }^{23}$ H. Kellmeyer, Das monistische System in der SE mit Sitz in Deutschland, "Zeitschrift für Wirtschaftsrecht”, Vol. 34/2003, p. 1534.

${ }^{24}$ H. Eidenmüller et al., op. cit., p. 203. 
form of involvement of employee stakeholders. The most creative solutions are found in the case of procedures for information and consultation, whereas the status quo is preserved during the employee involvement in the body of a company. This leads to the conclusion that the existing legal framework with regard to the development of employee involvement in the SE through negotiations is not effective in the case of participation. This may mean that the model system of participation created by the European Union legislature is adapted to the needs of stakeholders in European companies and does not need to be improved through negotiations.

The statistical data presented above indicate that with the increasing number of European companies, employee involvement in corporate governance of these companies also increases in various ways. Despite the fact that the legal solutions favouring the participation of employees at the transnational level have seemingly been adopted, this has not resulted in increased employee involvement in corporate governance that would be proportionate to the number of established SEs. The conducted analysis demonstrates that employee involvement in corporate governance is seen by entrepreneurs as a "braking driver" in the process of a European company formation ${ }^{25}$. In most created SEs, an "escape" from the implementation of stakeholder theory may be observed. This is done by setting up a European company without any employees or by choosing a method of its establishment that guarantees the least possible level of involvement of employees. Employee involvement is present only in 105 European companies, out of which the right of participation is enjoyed only by the employees of 54 . European companies "escape" from involvement of employees, despite the fact that the discussion in this regard has lasted for so many years and ended with seemingly conflict-free and flexible solutions.

Among the reasons for the above situation, the following ones may be pointed to: 1. delay in the process of creating an SE due to ongoing negotiations with regard to an agreement on employee involvement mechanisms 2 . need to incur the costs of negotiations on an agreement of company management and shareholders (costs of translations, transfer of information, expert opinions, travel costs); 3. presence of employee participation and the related requirement for the entrepreneurs to share "their assets". A constructional error is also present in the precondition for registration of an SE in the form of the need to determine employee involvement mechanisms, because in fact cases of companies without employees at the time of the registration process are not taken into account.

${ }^{25}$ W. Njoya, op. cit., p. 271. 
On the other hand, one may not fail to notice that the number of European companies guaranteeing their employees involvement in corporate governance is steadily increasing. It is worth noting that participative solutions are beginning to spread to countries which so far have not had such a tradition (eg. the United Kingdom). The country that has contributed to this is Germany, which, by having formed the largest number of "normal SEs", has transferred the tradition of employees' joint decision-making (Mitbestimmung) to other European countries. The range of this phenomenon is becoming ever ampler as also non-European countries such as the United States are considering the introduction of a European model of employee involvement in corporate governance ${ }^{26}$. This leads to the conclusion that the presence of employee stakeholders in corporate governance can still be seen as the future direction of development of transnational companies.

\section{BIBLIOGRAPHY}

Council Directive 2001/86/EC of 8 October 2001 supplementing the Statute for a European company with regard to the involvement of employees, OJ L 294/2001.

Council Regulation (EC) No. 2157/2001 of 8 October 2001 on the Statute for a European company (SE), OJ L 294/2001.

Eidenmüller H., Hornuf L., Reps M., Contracting Employee Involvement: An Analysis of Bargaining Over Employee Involvement Rules for a Societas Europaea, "Journal of Corporate Law Studies", Vol. 12, No. 2/2012, http://dx.doi.org/10.5235/ jcls.12.2.201.

Estlund C.L., Citizens of the corporation? Workplace Democracy in a Post-Union Era, New York University School of Law, Public Law \& Legal Theory Research Paper, No. 13-84/2013.

ETUI, Facts \& Figures, http://www.worker-participation.eu (15.03.2015).

Gesetz vom 22.12.2004 über die Beteiligung der Arbeitnehmer in der Europäischen Gesellschaft (SE-Beteiligungsgesetz) (The Act of 22.12.2004 on employees involvement in the European company), BGBI. I S. 3675, 3686.

Gesetz zur Ausfübrung der Verordnung (EG) Nr. 2157/2001 des Rates vom 8.10.2001 über das Statut der Europäischen Gesellschaft (SE) (SE-Ausführungsgesetz - SEAG) (Act implementing the Council Regulation (EC) No. 2157/2001 of 8 October 2001 on the Statute for a European company (SE)), BGBI. I S., 3675.

${ }^{26}$ C.L. Estlund, Citizens of the corporation? Workplace Democracy in a Post-Union Era, New York University School of Law, Public Law \& Legal Theory Research Paper, No. 13-84/2013, pp. 1-20. 
Keller B., Werner F., The establishment of the European Company: The First Cases form an Industrial Relations Perspective, "European Journal of Industrial Relations", Vol. 14, No. 2/2008, http://dx.doi.org/10.1177/0959680108089188.

Kellmeyer H., Das monistische System in der SE mit Sitz in Deutschland, "Zeitschrift für Wirtschaftsrecht", Vol. 34/2003.

Köstler R., Rose E., Mitbestimmung in der Europäischen Aktiengesellschaft (SE) Betriebs- und Dienstvereinbarungen, Verlag. Bund-Verlag, Frankfurt am Main 2011.

Njoya W., Employee Ownership in the European Company: Reflexive Law, Reincorporation and Escaping Co-determination, "Journal of Corporate Law Studies", Vol. 11, No. 2/2011, http://dx.doi.org/10.5235/147359711798110664.

OLG Düsseldorf, Beschl. v. 30.03.2009 - I-3 Wx 248/08, "Zeitschrift für Wirtschaftsrecht", Vol. 19/2009.

Oplustil K., Instrumenty nadzoru korporacyjnego (corporate governance) w spótce akcyjnej, Wydawnictwo C.H. Beck, Warszawa 2010.

Szymańska A., Włodarczyk P., Przedstawicielstwo pracowników w radzie spótki w krajach cztonkowskich UE, „Studia Prawno-Ekonomiczne”, Vol. 86/2012.

Taylor R., Industrial democracy and the European traditions, "Transfer: European Review of Labour and Research", Vol. 11, No. 2/2005, http://dx.doi. org/10.1177/102425890501100204.

Ustawa z dnia 4 marca 2005 r. o europejskim zgrupowaniu interesów gospodarczych i spótce europejskiej (Act of 4 March 2005 on European Economic Interest Grouping and European Company), Dz.U. No. 62, item 551.

van het Kaar R., The European Company (SE) Statute: up against increasing competition?, "Transfer: European Review of Labour and Research", Vol. 17, No. 2/2011, http://dx.doi.org/10.1177/1024258911401427.

Wratny J., Partycypacja pracownicza. Studium zagadnienia w warunkach transformacji gospodarczej, Wydawnictwo Instytutu Pracy i Spraw Socjalnych, Warszawa 2002. 